\title{
LA ARBITRABILIDAD DE LA CONTROVERSIA CONTENCIOSO-ADMINISTRATIVA EN EL ÁMBITO DE LAS RELACIONES CONTRACTUALES DEL ESTADO
}

\author{
THE ARBITRABILITY OF THE CONTENTIOUS ADMINISTRATIVE \\ CONTROVERSY IN THE FIELD OF THE STATE'S CONTRACTUAL \\ RELATIONS
}

\section{EdUARDo JeQuier LeHUEDÉ ${ }^{*}$}

\begin{abstract}
RESUMEN: Esta investigación trata sobre el arbitraje del conflicto contencioso administrativo en sentido lato, entendido como aquella controversia litigiosa sobre relaciones contractuales en que intervienen los particulares por una parte y, por la otra, los órganos de la administración pública en ejercicio de las potestades que el ordenamiento jurídico les confiere. Se trata de dilucidar el fenómeno de la arbitrabilidad en un ámbito que tradicionalmente ha estado proscrito al arbitraje como mecanismo alternativo de solución de conflictos, pero que poco a poco ha ido cediendo terreno frente al instituto arbitral sin que ello importe, en modo alguno, una vulneración de las potestades públicas privativas de la administración.
\end{abstract}

Palabras clave: Arbitraje, arbitrabilidad, contencioso administrativo, relaciones contractuales, órganos públicos, derechos subjetivos, potestades públicas, discrecionalidad administrativa.

ABSTRACT: This investigation deals about the arbitration of the contentious administrative conflict in a broad sense, understood as that litigious controversy about contractual relations in which intervene the individuals on one hand and, for other one, the organs of the public administration in exercise of the legal authorities that the juridical system awards them. This is to elucidate the phenomenon of arbitrability in an area that traditionally has been proscribed to the arbitration as alternative mechanism of conflicts solution, but has been gradually yielding ground to the arbitral institute without it means, in any way, a violation of the public exclusive legal powers of the administration.

Key words: Arbitration, arbitrability, contentious administrative conflict, contractual relations, public organs. subjective rights, public legal authority, administrative discretion.

\section{INTRODUCCIÓN}

La arbitrabilidad, en cuanto elemento esencial del arbitraje como herramienta heterocompositiva de conflictos litigiosos, tiene una directa vinculación con la noción de los derechos subjetivos. Cuando la ley vincula -en términos generales- la arbitrabilidad de la controversia a la disponibilidad de la materia que le da causa, lo que hace en último término es acotar el ámbito de lo arbitrable a aquellas pretensiones en las que se afirme por las

\footnotetext{
** Profesor de Derecho Comercial, Universidad de los Andes; profesor de Derecho Comercial y Derecho Económico, Universidad Católica del Norte. Correo electrónico: ejequier@uandes.cl - ejequier@ucn.cl

Doctor en Derecho, Universidad de Valencia; Magíster en Derecho de la Empresa, P. Universidad Católica de Chile.
} 
partes la titularidad de verdaderos derechos subjetivos, de manera que, como apunta Montero, "quien aparezca como actor tiene que afirmar la titularidad del derecho e imputar al demandado la titularidad de la obligación"1.

Sin embargo, parece necesario advertir no obstante que la arbitrabilidad así concebida, ligada necesariamente a la noción de los derechos subjetivos y a la concreta petición como parte de la pretensión, si bien se presenta como correcta y suficiente en el ámbito del Derecho privado, no explica ni justifica sin embargo el fenómeno creciente de apertura hacia la arbitrabilidad de aquellas controversias que, si bien traen causa en relaciones negociales reguladas por normas de derecho común, tienen como parte $-\mathrm{o}$ a alguna de ellas al menos- a los órganos de la administración del Estado.

En este ámbito concreto, en efecto, la concepción privatista de los derechos subjetivos escapa del todo a la configuración y justificación ontológica de aquellas potestades públicas que derivan de la soberanía y que se ejercen por el pueblo, a través de los poderes, autoridades y funcionarios que la Constitución y las leyes señalan. Por ello entonces, la arbitrabilidad en dicha esfera y, con ella, la facultad de los entes públicos para recurrir a arbitraje -cada vez más aceptada, según se dirá también- no puede explicarse al amparo de y en base a una concepción esencialmente privatista como la recién mencionada.

Dicho en otros términos, el obrar de los particulares, especialmente en sus relaciones entre sí, está sin duda inspirado y amparado por la libertad y la autonomía de la voluntad, de manera que estos pueden hacer y pactar todo aquello que sea atingente a sus derechos subjetivos y que no se encuentre expresamente prohibido por el ordenamiento jurídico, ya sea creando, modificando o extinguiendo las relaciones jurídicas que los vinculan. El accionar estatal, en cambio, está perfectamente delimitado por la Constitución y la ley, por lo que los órganos públicos solo actuarán válidamente en la forma y dentro del ámbito competencial que expresa y previamente se les señala y asigna, respectivamente ${ }^{2}$.

En lo que sigue nos proponemos dilucidar entonces si en estos casos, en que interviene como parte de la controversia respectiva un órgano de la administración del Estado, la opción pro arbitri constituye una excepción reservada a los casos expresamente autorizados por la ley, o si, por el contrario, dicha alternativa debe ser admitida en términos amplios cuando se trata de ciertas y determinadas materias, de naturaleza contractual como ya se adelantó.

Para abordar la tarea propuesta comenzaremos por determinar, en primer término, los aspectos a los que debe atenderse y que orientan por lo mismo el examen de arbitrabilidad del contencioso administrativo en general. La definición de tales factores, presentes según se verá en cada una de las situaciones en que el legislador chileno se ha pronunciado afirmativamente por esta vía heterocompositiva, nos permitirá plantear unas primeras pautas objetivas de discriminación entre materias que a nuestro juicio serán siempre susceptibles de arbitraje, aun cuando en su génesis haya intervenido un ente administrativo en ejercicio de sus potestades públicas, y aquellas otras que no lo serán en caso alguno, precisamente por la naturaleza y entidad de las potestades actuadas.

\footnotetext{
1 Montero (2004) p. 117.

2 Cfr. Fernández González (2002) pp. 38 y ss.
} 
Finalmente, y definido que sea el ámbito de las materias contencioso administrativas que a nuestro entender son arbitrables, nos detendremos a analizar los fundamentos dogmáticos de la señalada arbitrabilidad, ajenos como ya se dijo a la noción iusprivatista de los derechos subjetivos disponibles. En otros términos, procuraremos definir en esta parte de qué disponen concretamente los entes públicos que recurren a arbitraje sobre materias contractuales y si, para hacerlo, requieren realmente de una expresa autorización legal. Para ello, en fin, habremos de distinguir necesariamente entre el ejercicio de potestades que pertenecen al ámbito de la actuación reglada de los órganos públicos - por una parte- y la disposición discrecional de las consecuencias negociales de tales potestades -por la otra-, lo que permitirá explicar finalmente las razones por las cuales el arbitraje, al menos en estos casos, debe ser entendido como la regla y no como la excepción.

\section{EL CONTENIDO DE LA PRETENSIÓN COMO FACTOR DE ARBITRABILIDAD DE LA CONTROVERSIA CONTENCIOSO ADMINISTRATIVA}

La evolución del instituto arbitral en las últimas décadas demuestra cómo, cada vez más, materias consideradas comúnmente como inarbitrables han ido cediendo terreno a la arbitrabilidad en forma paulatina y creciente, abriéndose así camino a esta forma alternativa de solución de controversias en terrenos que comúnmente le estaban vedados. Es lo que ocurre, por ejemplo, con el arbitraje administrativo o de Derecho público y, más concretamente, a la arbitrabilidad de aquellas controversias que traen causa en materias del orden negocial en que interviene el Estado a través de sus órganos.

A la luz de la naturaleza colectiva de los intereses que gestionan los órganos públicos, cuyo actuar entronca además en el principio de legalidad que informa la actuación de la administración pública en general, el arbitraje ha sido tradicionalmente proscrito como alternativa heterocompositiva de los conflictos en que interviene la administración del Estado, de manera genérica y sin mayor discriminación dogmática. La jurisprudencia administrativa, como se dirá más adelante, ha restringido por lo mismo el acceso de los órganos estatales a la vía arbitral en términos radicales, al punto de reconocerla y autorizarla solo para aquellos casos en que la ley expresamente lo autoriza; y todo bajo la consigna genérica -e imprecisa por lo mismo- del carácter indisponible de las potestades privativas atribuidas por la Constitución y las leyes a las autoridades y órganos públicos.

Sin embargo, las rígidas y anquilosadas concepciones recién apuntadas, ancladas en criterios de tradición jurídica más que en razones concretas y sustentables, han venido reconociendo poco a poco en el arbitraje, de manera explícita en algunos casos e indirecta en otros, no solo un alivio para lo que algunos autores han calificado derechamente como una crisis de la justicia administrativa ${ }^{3}$, sino que una herramienta heterocompositiva perfectamente viable aun en este ámbito respecto de determinadas controversias ${ }^{4}$.

3 Cfr. García de Enterría(1989).

4 En el Derecho español, casos como los arts. 60 y 117 del RDL 2/2000, de 16 de junio, que aprueba el Texto Refundido de la Ley de Contratos de las Administraciones Públicas, los arts. 39, 104 y 112 del RDL 
Durante las últimas tres décadas, en efecto, diversas leyes han ido reconociendo en Chile la posibilidad de recurrir al arbitraje para la solución de conflictos derivados de relaciones jurídico-contractuales en las que el Estado interviene como parte, optando en todo caso el legislador por criterios de arbitrabilidad que van de un extremo al otro y que contemplan, por lo mismo, las más diversas posibilidades en tal sentido. De todas ellas, sin embargo, pueden extraerse algunos aspectos coincidentes que nos servirán como punto de partida para explorar con mayor detención el fenómeno de la arbitrabilidad de los conflictos en que participa la administración pública, mirados ahora bajo un prisma de discriminación dogmática que facilite la formulación de criterios comunes de diferenciación entre unos y otros, dependiendo de cuáles sean en definitiva las potestades públicas que actúan los órganos administrativos involucrados en cada caso. A partir de ahí, en fin, podrán definirse las pautas objetivas fundamentales a las que debe atenderse para la construcción de criterios interpretativos de general aplicación en esta materia, útiles sin duda cuando se trata aclarar aspectos que comúnmente $-\mathrm{y}$ con cierto grado de prejuicio incluso- se han mantenido en las penumbras de una mal entendida tradición.

\subsection{Algunos casos de arbitraje de la controversia contencioso-} administrativa contemplados en la ley Chilena. Planteamiento de una PREMISA COMÚN

Desde autorizaciones acotadas hasta la plena libertad de opción, la ley chilena contempla un variado elenco de posibilidades y criterios de arbitrabilidad del conflicto contencioso administrativo. Entre ellas sin embargo, como se adelantó supra, se observa un elemento que resulta común a todas y que radica, invariablemente, en la naturaleza contractual de la materia que origina el conflicto. Cumpliéndose dicho presupuesto, en fin, se regulan situaciones que en un extremo le confieren al órgano administrativo las más amplias facultades discrecionales para someter a arbitraje los conflictos derivados de sus relaciones contractuales, sin distinción ni limitantes; mientras que en el otro no faltan, por cierto, casos de arbitraje obligatorio en que el Estado está impedido incluso de eludir esta vía alternativa, por expreso mandato legal ${ }^{5}$.

1091/1988, de 23 de septiembre, que contiene el Texto Refundido de le Ley General Presupuestaria, o los arts. 7.3., 98.3 y 116 de la Ley 47/2003, de 26 de noviembre, Ley General Presupuestaria, por poner solo algunos ejemplos de los muchos que existen en la actualidad, se refieren expresamente al arbitraje como vía de solución de conflictos que, apenas algunas décadas atrás, estaban reservados a los órganos jurisdiccionales estatales. De manera más general incluso, el art. 107.2. de la Ley 30/1992, de 26 de noviembre, sobre Régimen Jurídico de las Administraciones Públicas y del Procedimiento Administrativo Común, reconoce explícitamente en el arbitraje una alternativa heterocompositiva que la ley sitúa a la par con los recursos administrativos de alzada y potestativo de reposición ante los tribunales estatales. Sobre esta normativa y la problemática que ha generado su aplicación en España, puede consultarse la obra de Delgado Piqueras (1995).

5 En el derecho comparado, y por poner también un ejemplo, la historia reciente del Derecho italiano ofrece algunas muestras en donde el arbitraje fue impuesto igualmente a las partes por mandato legal, precisamente en controversias de carácter contencioso-administrativas surgidas de relaciones contractuales entre la administración pública y los particulares. Para ello, sin embargo, se tuvo únicamente en cuenta la necesidad de descongestionar la vía judicial estatal en este ámbito, lo que constituye por ende una instrumentalización del arbitraje fundada en razones de política-judicial más que en fundamentos dogmáticamente sustentables, de cara a la naturaleza esencialmente voluntaria del instituto arbitral. 
Algunos ejemplos permitirán confirmar lo que se acaba de señalar:

\section{A) Casos de arbitraje forzoso}

Tratándose en primer término del arbitraje forzoso, y sin detenernos a analizar aquí la innegable contradicción conceptual que subyace en la imposición por ley del arbitraje sobre materias disponibles en derecho ${ }^{6}$, pueden citarse como ejemplos de lo dicho (a) el art. 36 de la Ley sobre Concesiones de Obras Públicas, D.F.L. Nº 164 del año 1991, cuyo texto refundido, coordinado y sistematizado fue fijado por el Decreto $\mathrm{N}^{\circ} 900$ del Ministerio de Obras Públicas, de 31 de octubre de 1996 (D.O. de 18 de diciembre de 1996), que regula el contrato de concesión de obras públicas; y (b) la Ley No 19.865, sobre Financiamiento Urbano Compartido (D.O. de 1 de abril de 2003), que establece también un sistema de Comisiones Conciliadoras que pueden transformarse en "Comisiones Arbitrales", similares en todo a los contemplados en la recién nombrada ley de Concesiones de Obras Públicas.

\section{B) Casos de arbitraje voluntario, limitados en razón de la materia del conflicto contractual}

Como ejemplos de autorización acotada según la materia -siempre en el ámbito de las relaciones contractuales de la administración del Estado, claro está- pueden mencionarse la Ley $N^{\circ} 18.803$ y su Reglamento (D.S. No 21 de 16 de enero de 1990, Ministerio de Hacienda), que autorizan a los servicios públicos regidos por el título II de la Ley $\mathrm{N}^{\circ} 18.575$ para encomendar contractualmente a las municipalidades o a entidades de derecho privado la realización de "acciones de apoyo a sus funciones que no correspondan al ejercicio mismo de sus potestades” (art. $1^{\circ}$ ). Según el art. 5 de la ley (art. 6 del Reglamento), y en lo que aquí concierne, se faculta expresamente a las partes respectivas -arbitraje voluntario por ende- para incorporar

Una completa exposición de los casos recién mencionados se contiene en D'Angeli (1996) p. 76, nota 151. Debe advertirse, sin embargo, que en algunos de los casos allí mencionados, como ocurre por ejemplo con la Ley No 109, de 19 de mayo de 1975, sobre Reordenamiento del Servicio Marítimo Postal y Comercial de carácter Local, lo que se somete a la determinación de un "collegio peritale, con funzione di arbitro inappellabile", es la fijación del precio de una determinada relación jurídica (art. 6, 20), lo que no constituye arbitraje desde que la función del árbitro no es allí jurisdiccional, sino de simple integración de una relación jurídica incompleta. Lo mismo ocurre en el caso -citado como ejemplo por la misma autora-del D.P.R. No 156, de 29 de marzo de 1972, que fija el Testo unico delle disposizioni in materia postale e di telecomunicazioni, art. 205.

Como señala LA CHina, sin embargo, es en este campo o sector de actividad en donde se observa una particular vulnerabilidad del Derecho italiano frente a lo que constituye, sin duda, una distorsión del instituto arbitral, esencialmente voluntario en su origen, pues aun cuando la intención de descongestionar la vía judicial parezca loable, se corre con ello -dice- el riesgo de crear en realidad una figura de jueces especiales (giudici speciali), violando así el artículo 102 de la Constitución cuando dispone que "Non possono essere istituiti (...) giudici speciali"; y con ello se vulnera -concluye el mismo autor- la garantía del artículo $24,1^{\circ}$, de la citada Carta fundamental, de poder actuar en juicio la tutela de los derechos propios. LA CHina (2004) pp. 4 y 5.

6 A este aspecto nos hemos referido ya en nuestro artículo "Examen de constitucionalidad del arbitraje forzoso en el ordenamiento jurídico chileno: algunas propuestas", en "Estudios Constitucionales", Centro de Estudios Constitucionales de Chile-CECOCH-, U. de Talca, Año 9, N², 2011, pp. 453-498.

7 Otros casos de arbitraje contencioso administrativo, como el contemplado en la Ley $\mathrm{N}^{\circ} 19.039$ sobre Propiedad Industrial y en la Ley $N^{\circ} 19.542$, sobre Concesiones Portuarias, pueden encontrarse en el trabajo de Carlos Carmona Santander, quien plantea que entre los años 1990 y 2004, en Chile se llevaron a cabo 78 procesos contencioso administrativos, de los cuales 6 fueron llevados a sede arbitral. Carmona (2005) pp. 183 a 240. 
a dichos contratos cláusulas arbitrales "para resolver los desacuerdos que puedan suscitarse entre los contratantes", optando así el legislador por un criterio indeterminado de atribución competencial a los árbitros que, por lo mismo, comprende todas aquellas controversias que traigan causa de la celebración y efectos de los contratos celebrados en el contexto material que fija la ley, incluyéndose en ello la nulidad de los mismos contratos ${ }^{8}$.

Sin perjuicio de lo anterior, la misma ley se encarga de aclarar también que las "acciones de apoyo a sus funciones", que pueden contratarse por la administración del Estado y someterse eventualmente a arbitraje en caso de desacuerdo, son solo aquellas "que no correspondan al ejercicio mismo de sus potestades (art. $1^{\circ}$ )". Tal criterio, cuyo trasfondo analizaremos con mayor detención en los apartados que siguen, apunta a nuestro entender al núcleo mismo de la problemática que pretendemos dilucidar, sirviendo por ende como base para la formulación de un planteamiento hermenéutico aplicable a simili a todas aquellas controversias surgidas en el marco de los contratos celebrados por los órganos de la administración pública, sin distinción tipológica y sin necesidad de una autorización legal previa y expresa.

\section{C) Casos de arbitraje voluntario de atribución discrecional amplia}

En otros casos, en fin, la ley ni siquiera condiciona la vía arbitral a una determinada materia de la que deba traer causa la controversia en que interviene el órgano público, sino que la autoriza de manera directa e incluso indirectamente.

a) Como ejemplos de la primera situación planteada, de autorización amplia y directa de arbitrabilidad, puede mencionarse (a) el caso contemplado en el art. 19 del D.L. No 2763 de 1979, que reorganiza el Ministerio de Salud y crea los Servicios de Salud (D.O. de 3 de agosto de 1979), en donde se autoriza expresamente al Director del Servicio de Salud respectivo, en cuanto jefe superior del Servicio, para designar árbitros en términos amplios, con la sola limitación de no poder asignarles la calidad de arbitradores ni otorgarles sus facultades a los que sean de derecho9; y (b) el caso regulado en el art. 58 de la Ley $N^{\circ} 18.482$ (D.O. de 28 de diciembre de 1985), interpretativo del art. 25 de la Ley No 6.440 (Ley Orgánica de la Corporación de Fomento de la Producción -CORFO-, D.O. de 10 de enero de 1941), en donde se

\footnotetext{
8 Sobre la independencia del convenio arbitral y el contrato al cual se incorpora -contrato principal- puede consultarse en Chile a Pereira (1996) p. 10; VÁsquez (2009) p. 216; y en el ámbito societario a Puelma (2000) p. 395.

9 Los mecanismos alternativos de solución de conflictos tienen una especial consagración en el ámbito de las controversias que surgen, entre los órganos públicos y particulares, con ocasión de las prestaciones del sistema de salud pública. Es así como la Ley N 19.966 de 2004, que establece un Régimen de garantías en Salud, crea en sus artículos 43 y sgtes. un mecanismo de mediación obligatoria entre el usuario afectado por la falta de servicio y el respectivo prestador institucional público de salud, a cargo -tratándose de esos prestadores- del Consejo de Defensa del Estado. Todavía más, la norma recién citada le asigna a esta gestión de mediación un carácter de requisito o presupuesto de procesabilidad del conflicto jurídico de que se trate, condicionando expresamente el acceso a los órganos jurisdiccionales al cumplimiento previo de la referida gestión. Sobre este aspecto, de dudosa consonancia con el derecho a la tutela judicial efectiva -en su vertiente de acceso a la jurisdicción- y con la naturaleza esencialmente voluntaria de la mediación en cuanto tal, puede consultarse a Gutiérrez Araque (2009) pp. 111 y ss.
} 
señala expresamente: "Art. 58.- Declárase, interpretando el artículo $25^{\circ}$ de la Ley $N^{o}$ 6.640, que la Corporación de Fomento de la Producción ha estado y está facultada para pactar toda clase de arbitrajes en los contratos que ella celebre".

b) Como ejemplo de la segunda situación mencionada, de autorización amplia e indirecta de arbitrabilidad como se dijo, puede citarse lo dispuesto por el art. 65 letra h) de la Ley $\mathrm{N}^{\circ}$ 18.695, Orgánica de Municipalidades (DFL $\mathrm{N}^{\circ} 1$, del Ministerio del Interior, D.O. de 26 de julio de 2006), en donde se le reconoce al alcalde -con el acuerdo previo del Concejo municipal- la facultad de transigir judicial y extrajudicialmente, lo que presupone necesariamente la disponibilidad de los respectivos derechos controvertidos y, por ende, la posibilidad de solucionar esa controversia por vía arbitral aun cuando la ley no lo diga expresamente. En otros términos, si la ley le reconoce aquí al órgano municipal la posibilidad de obtener la solución de una controversia jurídica por una vía directa y autocompositiva, sin la intervención de los órganos jurisdiccionales estatales por ende, no se divisa razón alguna para impedir que la misma consecuencia se obtenga por la vía arbitral, si las partes así lo quieren.

En síntesis, de lo dicho hasta aquí puede concluirse que no es el carácter público de los órganos administrativos lo que define per se la arbitrabilidad de los conflictos en que estos intervienen, ni tampoco la dimensión colectiva de los intereses que estos actúan según la Constitución y las leyes. En determinados casos, de naturaleza contractual y de índole patrimonial reitero, el ordenamiento jurídico autoriza sin reparos la vía arbitral como cauce procesal para la solución de los conflictos en que participa el Estado, lo que a nuestro entender constituye la regla general y no la excepción. Dicho en otros términos, el examen de arbitrabilidad del conflicto contencioso administrativo no se funda única y exclusivamente en su componente subjetivo, sino, más concretamente, en el contenido de la pretensión que se sostiene en cada caso. Como apunta Vásquez"10, en fin, "Aquí lo relevante es la naturaleza de la controversia y no la calidad del sujeto que participa en ella, de manera que serán arbitrables las cuestiones jurídico-privadas (como las relativas a bienes patrimoniales) aunque una de las partes sea una administración pública”.

Para fundar este último aserto, aun incompleto en su fundamentación, resulta necesario abordar a continuación algunos aspectos que nos parecen determinantes y que explican, precisamente, el porqué de la distinción que la propia ley ha hecho en esta materia según se acaba de demostrar.

\section{POTESTADES PÚBLICAS Y DERECHOS SUBJETIVOS; ALGUNAS DISTINCIONES NECESARIAS}

Queda por definir entonces el preciso sentido y el concreto alcance de la arbitrabilidad de la controversia que trae causa de relaciones contractuales en que interviene el Estado. Como se advirtió supra, pues, la noción privatista de los derechos subjetivos y su

10 VÁsQuez (2009) p. 595. 
libre disponibilidad en derecho no puede invocarse aquí como argumento suficiente para justificar la vía arbitral, ni siquiera en esta concreta esfera material.

\subsection{UNA PRIMERA DISTINCIÓN; PODER Y DERECHO SUBJETIVO}

Debe advertirse, en primer término, que los conceptos de potestad y derecho subjetivo, si bien pertenecen a un mismo género en cuanto manifestaciones del poder -en sentido lato- que el ordenamiento jurídico confiere para la tutela y/o el ejercicio de bienes jurídicos que considera relevantes, difieren no obstante uno del otro en términos sustanciales. Como apunta Santi Romano ${ }^{11}$, el poder en sentido estricto y el derecho subjetivo entrarían en el commune genus de los poderes en sentido amplio, en cuanto facultades de querer y de obrar que constituyen un núcleo común del género "poder jurídico", diferenciándose a partir de allí sin embargo en todas y cada una de sus notas distintivas. El primero -el poder-, "se desenvolvería en una dirección o aspecto genérico, no tendría objetos singularmente determinados, no se resolvería en pretensiones hacia otros sujetos y, por lo tanto, no sería correlativo a obligaciones"; mientras que el segundo -el derecho subjetivo-, por oposición al anterior concepto de poder o potestad, "se desenvolvería siempre en una concreta y particular relación jurídica con una determinada cosa o frente a determinadas personas que, por el contrario, tendrían obligaciones correspondientes".

De lo dicho se desprende, entonces, que la definición y la existencia misma de los derechos subjetivos depende necesariamente de una particular relación jurídica previa o subyacente, ya sea respecto de una cosa determinada o frente a otro(s) sujetos(s) de derecho, lo que por cierto no ocurre con las potestades públicas desde que su ejercicio, por parte del titular legitimado para ello por el ordenamiento jurídico, no precisa en modo alguno de una determinada relación jurídica preexistente. Tales relaciones o, en último término, esos sujetos -como dice el mismo autor ${ }^{12}$-, "pueden faltar enteramente; pueden no encontrarse en una posición de sujeción en relación al primero (titular de la potestad), y si se encuentran, no es ella correlativa al poder, sino solo un presupuesto suyo..." (el paréntesis es propio).

La noción de derecho subjetivo, en síntesis, discurre necesariamente sobre la base de la existencia previa de una relación jurídica concreta y determinada entre dos o más sujetos de derecho, que recae en un objeto también específico y que consiste además en una pretensión definida que tiene su contrapartida en un deber atribuible a un sujeto pasivo, que asume en tal sentido la calidad de sujeto obligado. La potestad en cambio, como apuntan García de Enterría y Fernández ${ }^{13}$, "no se genera en relación jurídica alguna, ni en pactos, negocios jurídicos o actos o hechos singulares, sino que procede directamente del ordenamiento... no recae sobre ningún objeto específico y determinado, sino que tiene carácter genérico y se refiere a un ámbito de actuación definido en grandes líneas o direcciones genéricas. No consiste en una pretensión particular, sino en la posibilidad abstracta de

\footnotetext{
11 Santi Romano (2002) p. 223.

12 Santi Romano (2002) p. 241.

13 Cfr. García de Enterría y Fernández (2006) pp. 447 y 448.
} 
producir efectos jurídicos, de donde eventualmente pueden surgir, como una simple consecuencia de su ejercicio, relaciones jurídicas particulares”.

\subsection{SEgunda Distinción NECESARIA; LA POTESTAD/PODER Y LA POTESTAD/FUNCiÓN}

Si bien no es el propósito de este trabajo el adentrarse en el estudio del arbitraje de Derecho público propiamente tal, existen sin embargo algunos conceptos fundamentales que deben aclararse para explicar, a partir de ellos, el contenido y el alcance de la arbitrabilidad como materia de análisis en este ámbito.

En un Estado de Derecho, la soberanía reside en el pueblo y se institucionaliza en el Estado organizado, en cuyo seno el poder se distribuye en fragmentos o medidas de ejercicio predefinidos por aquel conjunto de reglas fundamentales contenidas en la Constitución, que cada sociedad se da para modelar su propia convivencia. Se habla así, como apunta De la Cuétara ${ }^{14}$, de la potestad/poder, en cuanto manifestación potestativa que radica en el Poder Legislativo y en el Judicial y que, al mismo tiempo, es también poder desde que actúa en el ámbito superior del ordenamiento jurídico, en una dimensión creativa del Derecho cuyo límite superior es la propia Constitución; y se la distingue por ende de la denominada potestad/función, subordinada a la anterior y definida en el ordenamiento jurídico en atención a los fines que persigue, de servicio de los intereses generales y la obtención del bien común ${ }^{15}$. En esta última, en consecuencia, no se habla ya de poder sino de una "función administrativa" y, por ende, de "potestades funcionales" previamente asignadas por la Constitución y la ley, de manera que es precisamente esa función la que fija en definitiva los límites del ejercicio legítimo de las potestades conferidas para su ejercicio, a diferencia de lo que ocurre con la potestad/poder.

De lo dicho se sigue entonces una primera interrogante que debemos abordar:

Considerando que la función de los árbitros - no su naturaleza- tiene un carácter claramente jurisdiccional, al punto que el ordenamiento jurídico le atribuye al laudo la misma fuerza de cosa juzgada que a la sentencia definitiva emanada de los órganos jurisdiccionales del Estado; ¿significa entonces que esa función constituye una manifestación de la potestad/poder, tal como ocurre con el Poder Judicial? ¿ $\mathrm{O}$ se trata acaso de una potestad funcional al estar caracterizada precisamente por la función que cumplen los árbitros?

14 De la Cuétara (1986) p. 20.

15 La existencia de esta potestad funcional, diferenciada claramente de la potestad/poder, puede desprenderse de lo que disponen los artículos 103.1., 106.1. y 152.1. de la Constitución Europea, entre otros. Es lo que señalan también en Chile los artículos $2^{\circ}$ y $3^{\circ}$ del D.F.L. $N^{\circ} 1 / 19.653$ (D.O. de 17 de noviembre de 2001), que fija el texto refundido, coordinado y sistematizado de la Ley $\mathrm{N}^{\circ} 18.575$, Orgánica Constitucional de Bases Generales de La Administración del Estado. Según el primero, en efecto, Los órganos de la Administración del Estado someterán su acción a la Constitución y a las leyes. Deberán actuar dentro de su competencia y no tendrán más atribuciones que las que expresamente les haya conferido el ordenamiento jurídico... "La segunda de las normas citadas, por su parte, señala en su inc. $1^{\circ}$ que "La Administración del Estado está al servicio de la persona humana; su finalidad es promover el bien común atendiendo las necesidades públicas en forma continua y permanente y fomentando el desarrollo del país a través del ejercicio de las atribuciones que le confiere la Constitución y la ley, y de la aprobación, ejecución y control de politicas, planes, programas y acciones de alcance nacional, regional y comunal". $\mathrm{Y}$ es a esa potestad funcional a la que se refiere expresamente también el art. $5^{\circ}$ de la misma ley, entre otros, al señalar que "Las autoridades y funcionarios deberán velar por la eficiente e idónea administración de los medios públicos y por el debido cumplimiento de la función pública". 
La respuesta me parece necesariamente afirmativa en lo que toca a la primera interrogante, y negativa por ende en lo que concierne a la segunda. Así como los jueces y tribunales estatales ejercen una labor creativa del derecho, que no se limita por cierto a la mera aplicación de la ley al caso concreto, así también los árbitros ejercen la denominada potestad/poder al resolver una controversia jurídica entre partes cuando estas así lo han querido, en ejercicio del derecho fundamental de libertad de la persona humana y como manifestación consecuencial de la autonomía de la voluntad que el ordenamiento jurídico les reserva.

La anterior conclusión, si bien puede parecer evidente a la luz de la dogmática jurídica actual (aun cuando no han faltado quienes erradamente han identificado la función del Poder Judicial con la que ejerce la administración, en cuanto meros ejecutores de las leyes), no es sin embargo trivial a la hora de entender y justificar la perfecta pertinencia y legitimidad del arbitraje como herramienta heterocompositiva de determinadas controversias en este ámbito, surgidas de la confluencia de intereses público/privados y en la que intervienen, como se dijo, órganos públicos investidos de potestades funcionales. Por el contrario, es precisamente porque los árbitros ejercen una función jurisdiccional, inserta por ende en el orden de la potestad/poder, que las controversias entre particulares y los órganos públicos investidos de la potestad/función pueden ser conocidas y resueltas válidamente por aquellos en una relación potestativa superior (aun sin formar parte del Poder Judicial), siempre y cuando con ello no se afecte -reitero- el ejercicio mismo de tales potestades privativas de la administración.

\section{DISPONIBILIDAD Y ARBITRAJE ADMINISTRATIVO}

Hemos dicho antes que, en términos generales, las controversias en que intervienen los órganos del Estado no son ajenas per se al arbitraje, por la sola circunstancia de encontrarse -esos órganos- sometidos en todo a la Constitución y al principio de legalidad que informa su actuar. Como apunta Rodríguez Muñoz ${ }^{16}$, en fin, "los conflictos que puedan resolverse con el sistema arbitral han de ser de naturaleza disponible por las partes, es decir, han de referirse a materias sobre las que las partes puedan disponer válidamente conforme a Derecho, que en el ámbito del Derecho administrativo se corresponden con las materias típicamente convencionales, dejando al margen la actividad reglada de la Administración, pues en esta última la Ley permite una única solución justa”.

Corresponde definir ahora, entonces, el sentido que debe dársele aquí a la arbitrabilidad tal como la hemos descrito en los párrafos precedentes, para determinar en definitiva de qué están disponiendo concretamente los órganos públicos cuando recurren al arbitraje para la solución de sus conflictos de naturaleza contractual. Más aún, resulta de interés determinar las razones que permiten a los órganos públicos recurrir válidamente en estos casos a arbitraje, tanto a la luz de la normativa general de Derecho público que los rige -por un lado- y de la regulación especial sobre arbitraje que debe observarse simultáneamente -por el otro-. Se trata, en fin, de conciliar los principios de constitucionalidad y legalidad que describen y delimitan el actuar público, con los presupuestos esenciales que

16 Rodríguez (2011). Disponible en Aranzadi Westlaw, BIB 2011/1399 [consultado el 2 de abril de 2012]. 
deben cumplirse a su vez de cara al instituto arbitral en cuanto tal, desde su mismo origen (marcado por la voluntariedad de su fuente, a través de un convenio arbitral derivado de la autonomía de la voluntad) hasta su completa maduración en un laudo arbitral que será jurídicamente válido -en lo que aquí concierne al menos- solo en la medida que se ajuste precisamente al orden público imperante.

Como cuestión previa, sin embargo, y para dilucidar luego las interrogantes recién planteadas, me parece indispensable hacer algunas precisiones que eviten, nuevamente, cualquier confusión conceptual en torno a las ideas de potestad y derechos subjetivos; máxime si, como lo demuestra la práctica jurídica cotidiana, es común observar cómo el ejercicio del poder por parte de los órganos públicos genera relaciones jurídicas de las que se derivan, a su turno, derechos subjetivos y obligaciones correlativas que eventualmente podrían confundirse con el primero.

\subsection{Arbitraje y principio de SUjeción de la adMinistración al CONTROL} JUDICIAL. ¿ES COMPATIBLE LA JURISDICCIÓN ARBITRAL CON LA EXCLUSIVIDAD DE LOS ÓRGANOS JURISDICCIONALES ESTATALES ANTE LA CONSTITUCIÓN?

El arbitraje, en cuanto mecanismo alternativo de heterocomposición de conflictos de relevancia jurídica, reúne diversos elementos que lo caracterizan como una institución autónoma en donde confluye una diversidad de relaciones jurídicas concomitantes que le dan contenido y lo estructuran en su fase subjetiva y material. Entre aquellos elementos fundamentales se encuentran, en lo que aquí interesa destacar, la libertad que lo origina y justifica precisamente - por una parte- y la función heterocompositiva que le es propia -por la otra-, de carácter procesal por lo mismo.

Una visión conjunta de estos dos aspectos del arbitraje, fuente y función, genera espontáneamente la necesidad de destacar en primer término la perfecta relación y complementariedad que existe entre el arbitraje y el acceso a la tutela judicial efectiva y al juez ordinario predeterminado por la ley, que al igual que la libertad se reconoce también con carácter esencial en la Carta Fundamental de 1980. En otros términos, y partiendo de la base que la competencia y la facultad de administrar justicia corresponden únicamente al Poder Judicial ${ }^{17}$, ninguna incompatibilidad se genera al contemplar al mismo tiempo un mecanismo de equivalencia jurisdiccional que le reconozca a las partes la libertad para resolver sus disputas disponibles por medio de arbitraje. Como apunta Carazo ${ }^{18}$, comentando la sentencia del Tribunal Constitucional español No 56/1990, de 29 de marzo, "no es

17 Así lo señalan los artículos 117.3 y 149.1.5 de la Constitución española de 1978; y en Chile los artículos 76 y 77 de la Constitución Política de 1980, en relación con los artículos $1^{\circ}$ y $5^{\circ}$ del Código Orgánico de Tribunales. En Chile sin embargo, a diferencia de la experiencia española, la doctrina mayoritaria ha sostenido que a la luz de las normas constitucionales y legales precitadas, los árbitros tienen el carácter de jueces de la Nación y, por ende, de tribunales especiales que forman parte del Poder Judicial y que ejercen la actividad jurisdiccional del Estado, sometidos por lo mismo a la superintendencia directiva, correccional y económica de la Corte Suprema. No compartimos sin embargo esta opinión, pues los árbitros, si bien son considerados como jueces por el Código citado y ejercen jurisdicción en el plano declarativo, no forman parte del Poder Judicial ni se identifican en modo alguno con los órganos permanentes que lo componen. Los árbitros hacen lo que el Poder Judicial, pero no son Poder Judicial.

18 Carazo (2005) p. 56, nota 95. 
óbice al Derecho fundamental de todo ciudadano a acceder a la Administración de Justicia para solventar sus litigios el que de forma voluntaria estos renuncien a la actividad jurisdiccional para someterse a la resolución de los árbitros". El mismo TC reiteró posteriormente que "(...) no cabe entender que, por el hecho de someter voluntariamente determinada cuestión litigiosa al arbitraje de un tercero, quede menoscabado y padezca el derecho a la tutela judicial efectiva que la CE reconoce a todos. Una vez elegida dicha vía ello supone tan solo que en la misma ha de alcanzarse el arreglo de las cuestiones litigiosas mediante la decisión del árbitro y que el acceso a la jurisdicción legalmente establecido será solo el recurso por nulidad del L.A. y no de cualquier otro proceso ordinario en el que sea posible volver a plantear el fondo del litigio tal y como antes fue debatido en el proceso arbitral"l'.

Precisado lo anterior, queda por resolver entonces si la jurisdicción que ejercen los árbitros cumple con el estándar de juridicidad y de sujeción al control jurisdiccional que presupone el actuar administrativo, lo que nos lleva a plantear algunos aspectos relevantes del instituto arbitral.

\subsubsection{El arbitraje no implica renuncia de normas imperativas y de orden público}

En primer término, debemos destacar que la opción por este equivalente jurisdiccional no involucra en modo alguno una disposición de normas sustantivas de orden público, ni del derecho a un proceso con todas las garantías y ni siquiera de la intervención judicial en el proceso arbitral.

Una cosa es disponer en efecto del cauce procesal en el que las partes deciden resolver una determinada controversia jurídica, surgida en el marco de una determinada relación jurídico-contractual en este caso; y otra muy distinta lo es el disponer de las normas de fondo o sustantivas que la regulan en un caso determinado, con carácter imperativo o de ius cogens. En palabras de Vicent Chuliá20 "el compromiso de arbitraje es exclusión voluntaria del orden procesal pero no de la ley material aplicable, que en muchos casos será imperativa y a veces hasta de orden público, y, por tanto, los árbitros deberán aplicarla ineludiblemente". En otros términos, la circunstancia de que una determinada materia controvertida se encuentre sometida en su regulación material o de fondo a normas imperativas o de derecho necesario no implica, en modo alguno, que las partes no puedan optar por la vía arbitral para su solución heterocompositiva. Al hacerlo, en efecto, no están disponiendo de dichas normas - pues evidentemente no pueden hacerlo de manera válida-, sino únicamente de la vía procesal en la que estas habrán de aplicarse necesariamente.

Los árbitros, en síntesis, incluso los de equidad, están obligados a respetar en su laudo, en todo caso, las normas imperativas que regulan el asunto controvertido someti-

\footnotetext{
19 STC de 11 de noviembre de 1996, RTC 1996/176). Así lo decía expresamente por lo demás la Ley de Arbitraje española N 36/1988 en su Exposición de Motivos, al señalar que "El convenio arbitral no implica renuncia de las partes a su derecho fundamental de tutela judicial, consagrado en el artículo 24 de la Constitución", lo que se ve reflejado en la posibilidad de anulación del laudo en sede jurisdiccional ordinaria y en la intervención que se le reserva a la misma en la fase de ejecución del laudo, entre otros aspectos. Se trata, antes que eso, del derecho de optar por la solución arbitral renunciando a la jurisdicción estatal en su fase declarativa, y también en su fase ejecutiva cuando no se requiere de apremio en el Derecho chileno.

20 Vincente (2001) p. 114.
} 
do a su conocimiento y decisión, pues, en caso contrario, la sanción será la anulación del mismo laudo por afectar precisamente el orden público vigente. Así lo ha dicho la E. Corte Suprema en Chile, en su sentencia de 16 de septiembre de 1993, al señalar que "Los árbitros deben fallar conforme a la equidad, y siendo este un concepto objetivo, en su virtud deben los jueces árbitros respetar las normas del derecho positivo que tienen carácter de orden público (... '21. La Corte de Apelaciones de Santiago, por su parte, al acoger un recurso de queja por considerar infringidas normas que configuran el denominado "orden público procesal", dijo también en este sentido:

"Primero: Que, no obstante su carácter de arbitrador, según lo prescribe el artículo 223 del Código Orgánico de Tribunales, el juez árbitro está obligado a guardar en sus procedimientos y en su fallo las reglas que las partes expresan en el acto constitutivo del compromiso o, en su defecto, a las que se establecen para este caso en el Código de Procedimiento Civil. A este respecto, ha de indicarse que la doctrina y jurisprudencia son coincidentes en orden a que el amigable componedor debe observar las reglas comunes a todo procedimiento, contempladas en el Libro I del Código de Procedimiento Civil. En efecto, se ha dicho sobre el particular que constituye un grave error afirmar que los arbitradores tramitan en conciencia y como mejor les parezca. De modo diferente a esa aseveración, los árbitros arbitradores no son soberanos para la sustanciación o ritualidad del juicio" ${ }^{22}$.

De lo dicho se desprende entonces que ninguna diferencia puede existir en este sentido entre un órgano jurisdiccional estatal y uno arbitral, de cara a la solución de conflictos derivados de la ejecución de un contrato con repercusiones de índole estrictamente patrimonial, en que intervenga la administración pública. Ambos, tribunales estatales y arbitrales, deben sujetarse por igual a las normas imperativas y de ius cogens que regulan la controversia respectiva, de manera que no existe en este sentido una razón plausible para descartar a priori la intervención de árbitros en los casos recién mencionados.

\subsubsection{El arbitraje como equivalente jurisdiccional}

Relacionado siempre con el principio de juridicidad ${ }^{23}$ y su repercusión en el control jurisdiccional de los actos de la administración, verdadero freno de la potestad reglamentaria y de ejecución de la administración pública ${ }^{24}$, tampoco parece posible encontrar dife-

21 SCS, de 16 de septiembre de 1993, Recurso de Queja, Rol No 7.067.

22 SCA de Santiago, de 17 de agosto de 2006, Recurso de Queja "Metrogas Sociedad Anónima con Patricio Aylwin Azócar, Rol N²311-2006. Hay voto en contra. Disponible en http://www.poderjudicial.cl/index2. php?pagina1=estados_causas.php. Consultado el 3 de abril de 2012.

23 En palabras de Cazor y Pferffer, "El principio de juridicidad es un concepto que determina las relaciones entre el Derecho y los poderes públicos, de tal forma que toda actuación de los poderes constituidos supone la existencia de normas jurídicas que los vinculan cuando actúan y de esta forma los someten al Derecho. En este sentido, debe de ponerse de relieve que el principio de juridicidad expresa siempre y necesariamente una 'vinculación positiva', y no simplemente negativa, de la Administración al ordenamiento". Cazor y Pfeffer (2009) pp. 191-227.

24 Cfr. Santamaría (1988) p. 738. 
rencias sustanciales entre la jurisdicción que ejercen los tribunales estatales y la que desempeñan los árbitros respecto de materias arbitrables, según sostenemos en este caso.

En Chile, en efecto, la gran mayoría de los autores y la jurisprudencia mayoritaria de los tribunales superiores de justicia ${ }^{25}$ se pronuncian explícita y decididamente por la naturaleza jurisdiccional del arbitraje. Así lo destaca entre otros Romero ${ }^{26}$, al señalar que "aunque en doctrina y legislación procesal extranjera, condicionadas por su propia realidad jurídica, se discute sobre el carácter jurisdiccional del arbitraje, entre nosotros (en Chile) pacíficamente se ha sostenido desde hace bastante tiempo el contenido jurisdiccional de la justicia arbitral (...) con las limitaciones que le son propias, y que dicen relación con la falta de imperio (...)”.

En este sentido entonces, y si bien discrepamos de la tesis referida -pues confunde la función jurisdiccional que desempeñan los árbitros con la naturaleza jurídica de un instituto de origen esencialmente voluntario-, lo cierto es que ella refuerza sin duda la propuesta que aquí sostenemos, en cuanto a la perfecta incardinación de la justicia arbitral en el ámbito del contencioso-administrativo de índole patrimonial. Como apunta Montero, por lo demás, la jurisdicción es una sola, de manera que "no cabe decir que [la jurisdicción] cumple funciones distintas, sino que la única función se actúa en ámbitos distintos, a riesgo de tener que llegar a la conclusión de que la función es distinta en los diversos tipos de proceso, es decir, de actividad jurisdiccional" 27.

La jurisprudencia del TC español en cambio, sin llegar a la asimilación funcional entre los jueces estatales y los árbitros como ocurre en la jurisprudencia nacional, ha optado por considerar al arbitraje como un equivalente jurisdiccional, señalando por ejemplo:

“A tenor de la Ley de Arbitraje de 1988, el árbitro que zanja una controversia mediante un laudo de Derecho actúa en ejercicio de una potestad de iuris dictio, pues el arbitraje es un «equivalente jurisdiccional», mediante el cual las partes pueden obtener los mismos objetivos que con la jurisdicción civil, esto es, una decisión que ponga fin al conflicto con todos los efectos de la cosa juzgada (SSTC 62/1991 [RTC

\footnotetext{
25 Así lo ha entendido la Corte Suprema, al señalar por ejemplo que "El arbitraje voluntario es una especie de jurisdicción establecida en la ley...", agregando luego que "El Código Orgánico de Tribunales consulta entre las diversas categorías de jueces a los árbitros, y reconoce en ellos una de las formas de jurisdicción establecidas para la resolución de determinados asuntos ..." (SCS, de 17 de octubre de 1955, en Revista de Derecho, Jurisprudencia y Ciencias Sociales y Gaceta de los Tribunales, Tomo LII, 2a parte, sec. 1a, Edit. Jurídica de Chile, Santiago, 1955, pág. 337). La Corte de Apelaciones de Santiago ha declarado a su turno que los jueces árbitros administran justicia y desempeñan por lo mismo " $3^{\circ}$... una función pública, toda vez que la jurisdicción es atributo exclusivo del Estado y solo los órganos por él autorizados pueden ejercerla. Los árbitros derivan su jurisdicción de la propia ley, que se les otorga con el carácter de extraordinaria”. (SCA de Santiago, de 29 de agosto de 1986, en El arbitraje en la jurisprudencia chilena, Centro de Arbitraje y Mediación, Cámara de Comercio de Santiago, Santiago de Chile, 2005 , pp. 80 a 82 ).

26 Romero (1999) p. 484. La tesis mencionada no es nueva en Chile, pues ya la proponía Ballesteros a fines del siglo XIX. Según este autor, la legislación chilena (se refería obviamente a la Lei de Organización de los Tribunales, cuyo artículo 172 es del todo idéntico al artículo 222 del COT) hace del arbitraje "una jurisdicción", por lo que las partes debían acatar sus sentencias o laudos como si emanaren de los jueces ordinarios. BALLESTERos (1890) p. 74. También puede consultarse la obra de Aravena (1969) pp. 22 y ss.

27 Montero (2000) pp. 127 y 128.
} 
199/162], fundamento jurídico 5. ${ }^{\circ}$ y 288/1993 [RTC 1993/288], fundamento jurídico 3. ${ }^{\circ}$ ). Su declaración de los derechos y obligaciones recíprocas de las partes de la controversia se encuentra revestida de auctoritas, por imperativo de la Ley; y solo carece del imperium necesario para ejecutar forzosamente su decisión, que la Ley vigente reserva a los Tribunales civiles" 28.

Igual declaración hace el TC en su sentencia de 14 de octubre de 2002:

“...porque el simple examen acerca de si el ejercicio de una pretensión procesal es o no jurídicamente viable no puede, en modo alguno, equipararse al enjuiciamiento sobre el fondo de aquella, que es la función que ha de quedar siempre reservada, «ex» art. 117.3 CE, a los Juzgados y Tribunales o, en su caso, a los órganos arbitrales, como equivalente jurisdiccional [STC 12/1998, F. 4 b)]"29.

Más clara aun es la STC de 13 de noviembre de 1997:

“...como ya ha tenido ocasión de señalar este Tribunal, pues «siendo el arbitraje un equivalente jurisdiccional, mediante el cual las partes pueden obtener los mismos objetivos que de la jurisdicción civil, esto es, la obtención de una decisión que ponga fin al conflicto con todos los efectos de la cosa juzgada, es evidente que la creación de órganos de naturaleza arbitral y el establecimiento de dicho procedimiento es materia propia de la legislación procesal civil, relacionada, en cuanto a los efectos del laudo arbitral y al sistema de recursos, con la Administración de Justicia» (SSTC 15/1987 [RTC 1987/15], fundamento jurídico 9, b); 62/1991 [RTC 1991/62], fundamento jurídico 5)"30.

En síntesis, y si bien es cierto que en nuestro ordenamiento jurídico todas las actuaciones de la Administración del Estado se encuentran sujetas a su ulterior revisión judicial, ningún inconveniente existe en que tal escrutinio sea entregado a árbitros cuando lo revisable sean las consecuencias patrimoniales que se derivan de su condición de contratante. Por lo anterior, y tratándose concretamente de aquellos conflictos en que interviene la Administración del Estado en fase de ejecución contractual, coincidimos con GIL CRUZ ${ }^{31}$ cuando afirma que "se debe intentar traspasar las técnicas convencionales que ponen fin a los conflictos de la esfera privada (a través de la autonomía de la voluntad de las partes), al campo del Derecho administrativo con el fin de minorar los conflictos en esta área, mediante una conjunción de ambos campos". Tal mecanismo, como se dijo supra, constituye una vía jurisdiccional de equivalencia a través de la cual las partes "pueden obtener los mismos objetivos que de la jurisdicción civil, esto es, la obtención de una decisión que ponga fin al conflicto con

\footnotetext{
28 ATC de 28 de octubre de 1993, en Aranzadi Westlaw, RTC 1993/326.

29 STC, 14 de octubre de 2002, en Aranzadi Westlaw, RTC 2002/182.

30 STC, 13 de noviembre de 1997, en Aranzadi Westlaw, RTC 1997/196.

31 Gil Cruz (2010).
} 
todos los efectos de la cosa juzgada", aunque con un beneficio adicional tanto para el particular involucrado cuanto para el interés general que informa el actuar administrativo: la solución rápida y eficaz del conflicto entre las partes.

Nos parece, con todo, que el arbitraje debiese ser en estos casos uno de derecho, sometido por ende a las normas legales que regulan el fondo de la materia controvertida y el procedimiento aplicable en cada caso ${ }^{32}$.

\subsection{LAS pOtestades QUE GENERAN RELACIONES JURÍdicas: ¿SON DEREChos SUBJETIVOS?}

Lo primero que debe destacarse entonces, en el sentido recién apuntado, es que la existencia de una concreta relación obligacional entre el órgano dotado de potestad y los sujetos de derecho que se relacionan con él, en nada desfigura la naturaleza de esta última en cuanto tal. Dicho de otra forma, si bien es cierto que en este ámbito de las potestades públicas es la legalidad la que define y delimita el actuar de la Administración (al punto que esta no puede actuar, en modo alguno, sin una específica atribución previa de potestades), al mismo tiempo debe tenerse en cuenta que el ejercicio de ese poder o potestad, atribuido previamente por el ordenamiento jurídico, no se transforma en derecho subjetivo por el solo hecho de generar a su vez relaciones jurídicas de las que se deriven obligaciones determinadas, ya sea para el propio órgano público o para los sujetos que se relacionan con él. Tales obligaciones, por el contrario, surgen a la vida del Derecho precisamente como consecuencia del ejercicio legítimo de una parcela o medida de poder por parte del órgano asignatario de la misma, de lo que se sigue que la potestad pública asume por ende el carácter de antecedente y presupuesto de dicha relación obligacional, aunque sin llegar a identificarse con ella.

En estos casos, por ende, los derechos subjetivos que surgen de esa relación jurídica se independizan del poder que les dio origen, adoptando singularidad propia. Del mismo modo, y por consiguiente, tampoco la existencia de una concreta relación obligacional entre el órgano dotado de potestad y los sujetos de derecho recién mencionados desfigura la naturaleza de esta última en cuanto tal. El poder o potestad, en fin, no se transforma en derecho subjetivo por el solo hecho de generar relaciones jurídicas de las que se deriven obligaciones determinadas, ya sea para el propio órgano público o para los sujetos que se relacionan con él, pues esas obligaciones, cuando surgen a la vida del derecho, lo hacen precisamente como consecuencia del ejercicio del poder que le sirve así de antecedente y presupuesto.

\footnotetext{
32 Advirtamos que esta opción no implica un diferenciamiento cualitativo entre el arbitraje de derecho y el de equidad, en cuanto mecanismos igualmente eficientes de solución de controversias, pues "concurriendo el requisito de la arbitrabilidad, no existen materias que tengan que ser resueltas por arbitraje de derecho y no de equidad" (Sentencia Audiencia Provincial de Madrid, de 24 de septiembre de 2002, Aranzadi Westlaw, JUR 2003\22969). Sin embargo, nos parece que a la luz de la estructura actual del arbitraje interno en Chile, obsoleta por cierto, el sometimiento pleno de los árbitros a Derecho parece cumplir de mejor forma el estándar que impone el principio de sujeción plena de la administración al control jurisdiccional, a lo que se suma la dificultad de incardinar la naturaleza y fines de los órganos públicos con la exigencia contemplada en el art. 224 del Código Orgánico de Tribunales.
} 
Podemos afirmar con Santi Romano ${ }^{33}$, en síntesis, que "el poder engendrará en algunos casos la relación de la cual es un elemento la obligación, juntamente con el derecho correlativo, pero el progenitor, precisamente por serlo, no es el hijo".

\subsection{LAS POTESTADES DISCRECIONALES COMO FUENTE DE ARBITRABILIDAD.}

Hemos establecido antes, en base a la clasificación jerárquica del poder y a la determinación de los poderes del Estado que lo ejercen en conformidad a la Constitución y las leyes, que los árbitros pueden, en determinadas casos, resolver válidamente y con perfecta sujeción al ordenamiento jurídico las controversias que surgen del ejercicio de tales potestades públicas, generadoras de relaciones jurídico-contractuales concretas.

Hemos dicho también que, sin embargo, esas relaciones jurídicas, surgidas de la actividad del órgano público en ejercicio de las potestades mencionadas, no pueden confundirse en modo alguno con estas últimas en cuanto manifestación del poder soberano, las que conservan por ende su naturaleza de orden público, indisponibles en derecho.

Por lo anterior entonces, necesario resulta concluir que es en el preciso ámbito de estas relaciones jurídicas consecuenciales, surgidas del ejercicio de las potestades legales antes mencionadas, en donde el arbitraje encuentra campo fértil como herramienta alternativa de solución de controversias. Es lo que destacan precisamente Merino y Chillón ${ }^{34}$, al advertir que "al encontrarse los poderes públicos sujetos a la Constitución y al resto del ordenamiento jurídico (art. 9.1. CE), queda acotado como campo propicio para el arbitraje administrativo el de las actividades básicamente convencionales, entre las que destacan naturalmente las típicamente contractuales".

Llegamos entonces al punto de determinar, concretamente, cómo y de qué disponen los órganos del Estado cuando, facultados para ello, recurren al arbitraje para la solución de las controversias que les incumben; interrogante esta que requiere nuevamente la aclaración previa de algunos conceptos que, aunque básicos, resultan sin embargo fundamentales en esta parte.

33 Santi Romano (2002) p. 236.

34 Merino y Chillón (2006) p. 305. Advierten estos autores que en virtud del principio de constitucionalidad y por aplicación del principio de legalidad, respectivamente, en este ámbito del Derecho público el arbitraje debe ser necesariamente de derecho y no de equidad, salvo aquellos casos en que se deban resolver cuestiones de hecho o de simple determinación económica. No coincido sin embargo con este criterio, que confunde al parecer la arbitrabilidad de la controversia de que se trate con el carácter imperativo o de ius cogens de las normas que regulan la materia que le da causa. Las partes, en tales casos, no disponen por cierto de tales normas de Derecho necesario (pues simplemente no tienen facultad para hacerlo), sino simplemente del cauce procesal para resolver la controversia respectiva cuando esta trae causa de materias disponibles en derecho. Una cosa es someter entonces a arbitraje conflictos sobre materias reguladas por normas de fondo imperativas, y otra muy distinta es que el árbitro las infrinja efectivamente en su laudo, sea que se trate de un arbitraje de derecho o de equidad. Lo primero no presenta inconveniente alguno, aun en el arbitraje de equidad, en la medida que el árbitro no afecte el orden público objetivado en la norma de ius cogens y que la pretensión concreta sea disponible en Derecho, esto es, cuando los particulares puedan obtener el bien o la consecuencia jurídica asociada a la norma de Derecho de manera directa, sin necesidad de una sentencia dictada por un órgano jurisdiccional estatal. Como apunta Montero, "Cuando la consecuencia solo pueda hacerse efectiva por medio de sentencia estaremos ante materia de no libre disposición” [Montero (2004) p. 121)]. 
En efecto, una de las distinciones capitales que encontramos en la doctrina administrativa -sin entrar a su estudio detallado, reitero- apunta precisamente al modo en que estas potestades administrativas son asignadas en cada caso por el ordenamiento jurídico, discriminando de tal forma entre dos grandes grupos o sistemas de atribución potestativa: las potestades regladas y las potestades discrecionales.

A) En las primeras - las regladas-, la autoridad administrativa debe limitarse a constatar simplemente el supuesto de hecho incorporado en la norma legal atributiva de la potestad, el que viene definido de manera completa y hasta "agotadoramente" -como señalan García y Fernández ${ }^{35}$-, abarcando todas y cada una de las condiciones de ejercicio de dicha potestad. La administración, por ende, debe verificar simplemente la concurrencia de tal supuesto y, desde allí, debe ejercer consecuencialmente la potestad que la misma ley describe y delimita, "también agotadoramente", para dichos casos en concreto. Existe aquí, en fin, "un proceso aplicativo de la Ley que no deja resquicio a juicio subjetivo ninguno, salvo a la constatación o verificación del supuesto mismo para contrastarlo con el tipo legal”36.

B) En las restantes en cambio -las discrecionales-, el mecanismo de aplicación de la ley pertinente, que atribuye las potestades respectivas, le asigna a la Administración una intervención esencialmente subjetiva, integradora por ende de la norma legal desde que esta, en cuanto fuente legitimadora indispensable del ejercicio de toda potestad jurídica, se limita solo a definir alguna(s) de las condiciones para su ejercicio. Es la evaluación subjetiva del órgano administrativo la que determina en estos casos la forma en que habrá de completarse la norma legal atributiva de potestades, ya sea en cuanto a la realización concreta del supuesto de hecho (por ejemplo la designación electiva de cargos administrativos), ya en lo que concierne al contenido específico, en el caso concreto, de la decisión que deberá adoptar el administrador premunido de potestad (como ocurre por ejemplo con la fijación de las obligaciones que deberá cumplir el beneficiario de un Permiso Municipal precario). Desde el punto de vista del acto administrativo, en fin, serán discrecionales aquellos en que la entidad administrativa muestra un menor grado de vinculación a la norma legal en cuanto a la determinación de la vía idónea para la consecución de los fines que le asignan; o en términos asertivos, "aquellos en que la Administración actúa con mayor libertad, pues su conducta no está determinada por una norma legal, sino por una predeterminación genérica, dada por la finalidad legal a cumplir" 37 .

Advirtamos, sin embargo, que el ejercicio de estas potestades y la ejecución de estos actos no constituye en modo alguno una facultad originaria de la Administración, anterior y/o ajena al ordenamiento jurídico que la concede y reconoce. Antes por el contrario, el órgano administrativo está facultado en ciertos casos para actuar del modo antes descrito porque, precisamente, es la ley la que lo ha señalado así de manera explícita, diseñando el ejercicio de las potestades respectivas con ese preciso carácter. Y tampoco puede la autoridad administrativa, por lo mismo, ejercer sus poderes discrecionales para cualquier propósito, pues el fin de las potestades discrecionales constituye no obstante un elemento

\footnotetext{
35 García de Enterría y Fernández (2006) p. 459.

36 García de Enterría y Fernández (2006) p. 459.

37 SaAvedra (2011) p. 15.
} 
reglado por la ley, sobre la base omnipresente del interés común en cuanto baremo del actuar administrativo y de la medida de sus potestades en general. Dicho en otros términos, y como apunta también García de Enterría ${ }^{38}$, no es cualquier finalidad la que autoriza el ejercicio de estas potestades discrecionales, "sino precisamente de la finalidad considerada por la Ley, y en todo caso de la finalidad pública, de la utilidad o interés general”. Será, en síntesis, el fin de interés público que la ley le señale al órgano público de manera específica, pues, como señala Vedel ${ }^{39}$, "no es suficiente que la Administración persiga un fin de interés público cualquiera, puesto que en la mayor parte de los casos una autoridad administrativa ha recibido tal poder para un fin determinado de interés público y no puede utilizarlo para otro distinto". La discrecionalidad, en fin, no es arbitrariedad ${ }^{40}$.

Todavía más, y como advierte Moraga ${ }^{41}$, es un hecho evidente que las atribuciones administrativas son asignadas en cada caso con mayor o menor taxatividad por la ley, aunque siempre en función de la finalidad que se le atribuye al ente administrativo de que se trate. Pues bien, una designación potestativa que sea en cierto modo estrecha o ambigua no implica, sin embargo, que el órgano respectivo se encuentre imposibilitado de actuar en la vida del derecho, pues junto a las atribuciones explícitas o taxativas se encuentran aquellas otras que son inherentes al cumplimiento de los fines asignados al órgano público, pese al vacío de la ley. Se trata -dice este autor- de atribuciones esenciales que articulan "facultades o poderes que innegablemente pertenecen al órgano público aun cuando ellos no se encontraren escritos, y que no pueden ser negados a partir de una justificación de legalidad formal”.

Asimismo, existen muchos ámbitos de actuación en que las administraciones públicas conservan un cierto poder de autoorganización que, como apunta Moraga ${ }^{42}$, "le permite celebrar contratos y convenios para el adecuado funcionamiento de sus servicios públicos", sin que sea necesario tampoco, en esos casos, que la ley los faculte expresamente para pactar las cláusulas que le parezcan más convenientes de cara al cumplimiento de sus fines propios (y la solución rápida y eficaz de sus conflictos contractuales por cierto que encaja dentro de ese elenco de funciones inherentes). Bastará al efecto -dice el mismo autor- "que el órgano administrativo que actúe tenga la competencia legal para organizar y dirigir el servicio público u oficina administrativa a su cargo", lo que permite concluir que "la administración del Estado puede celebrar, en principio, los contratos, acuerdos, pactos y convenciones que tenga por convenientes para la prosecución del fin específico de interés general al que se debe”, sin necesidad de ley que lo autorice previamente. Se trata, en fin, de una manifestación legítima de discrecionalidad administrativa contractual, que le permite al ente administrativo pactar todas aquellas cláusulas contractuales -incluida la de arbitraje- que no sean contrarias a la Constitución, la ley, el orden público y a los fines del propio órgano.

38 García de Enterría(1983) p. 27.

39 VEDEL (1980) p. 259.

40 Cfr. SaAvedra (2011) p. 36; Soto Kloss (1982) pp. 189-190.

41 Moraga (2008) pp. 277-324.

42 Moraga (2007) pp. 32 y ss. 
En conclusión, cuando afirmo que la administración del Estado se encuentra perfectamente facultada para optar por la vía arbitral, en los casos de ejecución contractual mencionados supra, lo hago en el entendido que tal opción constituye precisamente una manifestación de las potestades discrecionales que el ordenamiento jurídico le confiere a los órganos que la componen, tomando como base el interés general y, concretamente, aquella parcela de interés común que la ley les asigna en cada caso. Por lo mismo, no se requiere aquí, a mi entender, de una concreta y explícita autorización legal para que los órganos de la administración, vinculados contractualmente con terceros, puedan someter a arbitraje la solución de sus controversias en el ámbito ya dicho.

\subsection{Lo que ha señalado la jurisprudencia administrativa en Chile}

Debe advertirse, por último, que las conclusiones apuntadas supra no han sido compartidas por alguna jurisprudencia administrativa en Chile. Según esta última, en efecto, los órganos de la administración del Estado requieren de una autorización legal expresa para someter a arbitraje los conflictos en que sean parte ${ }^{43}$.

El criterio recién apuntado, sin embargo, no resulta acertado como criterio general de arbitrabilidad, aplicable incluso en el ámbito contractual en el que nos hemos centrado. Por el contrario, y en último término, el recurso a la vía arbitral como mecanismo de solución de las controversias de naturaleza contractual que afecten a los órganos de la administración del Estado, según ya se explicó, debe entenderse restringido solo cuando la ley lo señale expresamente y no al revés. Es lo que ocurre, por ejemplo, con la Disposición Adicional Primera de la ley española sobre contratos de las Administraciones públicas (texto refundido aprobado mediante Real Decreto Legislativo 3/2011, de 14 de noviembre, BOE $\mathrm{N}^{\circ} 276$ de 16 de noviembre de 2011) ${ }^{44}$ y, en Chile, con lo dispuesto en los artículos 22, 52 y 60 del D.F.L. $\mathrm{N}^{\circ} 1$, de 2005, del Ministerio de Salud (fija el texto refundido, coordinado y sistematizado del D.L. $\mathrm{N}^{\circ} 2.763$, de 1979 y de las leyes $\mathrm{N}^{\circ} 18.933$ y $\mathrm{N}^{\circ} 18.469$ ), que prohíbe expresamente que el respectivo Director del Servicio de Salud, en cuanto jefe superior del Servicio, designe árbitros en calidad de arbitradores o que le otorgue sus facultades a los que sean de derecho. Tal limitante, en fin, carecería de toda justificación de seguirse el criterio administrativo referido supra.

\footnotetext{
43 Véanse en este sentido, por todos, los Dictámenes de la Contraloría General de la República $\mathrm{N}^{\circ} 10.657 / 1985, \mathrm{~N}^{\circ} 14.810 / 1991, \mathrm{~N}^{\circ} 344 / 1996, \mathrm{~N}^{\circ} 17.160 / 1996$ y No $54.844 / 2003$.

44 Según esta disposición, "En los contratos con empresas extranjeras se procurará, cuando las circunstancias lo aconsejen, la incorporación de cláusulas tendentes a resolver las discrepancias que puedan surgir mediante fórmulas sencillas de arbitraje. Igualmente se procurará incluir cláusulas de sumisión a los Tribunales españoles. En estos contratos se podrá transigir previa autorización del Consejo de Ministros o del órgano competente de las Comunidades Autónomas y entidades locales". La señalada norma adicional ha llevado a la doctrina en España a sostener el mismo criterio amplio de arbitrabilidad para todos los contratos en que intervenga el Estado. En opinión de Gil Cruz, en efecto, "Si a nivel internacional es posible que el Estado o los organismos o entidades controladas por el Estado en los contratos que celebren incluyan convenios arbitrales en los que se obligan a acatar el laudo que al respecto se dicte y en los que al obligarse la Administración entra en juego el orden público y el interés general, no entendemos, desde nuestra modesta opinión, las limitaciones e incluso la prohibición que a nivel del Derecho interno establecen distintos legisladores pues el sustento de la solución de conflicto a través de técnicas extrajudiciales es la buena fe así como la seguridad jurídica, pilares que deben ser los mismos tanto a nivel nacional como internacional (Gil Cruz, Eva Ma., op. cit.).
} 
En otros términos, si la vía arbitral debe ser autorizada expresamente por la ley, como sostiene la precitada jurisprudencia administrativa, ningún sentido y propósito tendría que la misma ley -como en el caso recién apuntado- lo prohíba o delimite explícitamente en determinadas situaciones, o que lo imponga en otras. No se trata en estos casos, reitero, de aquella facultad de disponer de derechos subjetivos propia del derecho privado, según la concreta pretensión de las partes involucradas en una controversia determinada -pues ya se dijo que los órganos públicos no los tienen-, sino del ejercicio de potestades públicas que encuentran su fundamento en la Constitución y la ley y que, precisamente, facultan al órgano administrativo para optar discrecionalmente por la vía arbitral. Serán esas concretas materias, entonces, las disponibles en derecho como parámetro de arbitrabilidad.

La jurisprudencia extranjera ha tenido oportunidad de ocuparse también de este aspecto, pronunciándose favorablemente sobre la arbitrabilidad de aquellas controversias surgidas de actos de carácter negocial, en que intervienen como partes determinados órganos públicos. Ejemplo reciente de ello lo encontramos en la jurisprudencia del Tribunal Superior de Justicia de Brasil, que a partir del 25 de octubre de 2005, en una sentencia considerada pionera en este ámbito, declaró la perfecta procedencia de la cláusula de arbitraje en un contrato de suministro de energía eléctrica, previamente licitado, en el que intervenía precisamente como parte una empresa del Estado. En dicha sentencia, el tribunal deja en claro que para ello el ente público no requiere de autorización legal expresa, agregando que si en el contrato respectivo las partes -empresa estatal incluida- estipulan que las controversias entre ellas acerca de las obligaciones acordadas será dirimida mediante árbitros, estará definitivamente impuesta como obligatoria la vía extrajudicial ${ }^{45}$.

Enfática ha sido también, en el ámbito internacional, la Convención Europea de 1961 sobre Arbitraje ("European Convention on International Commercial Arbitration" o Convención de Ginebra), que en el título "Right of Legal Persons on Public Law to Resort to Arbitration", art. 2.1, señala: "En los casos referidos en el art. I. I, de esta convención, las personas jurídicas consideradas por la ley a ellas aplicable como 'personas jurídicas de derecho público', tienen el derecho de celebrar válidamente convenciones arbitrales" 46.

\section{CONCLUSIONES}

De lo analizado en el presente trabajo puede concluirse, como criterio de arbitrabilidad aplicable a todas las relaciones contractuales en las que intervengan el Estado y sus órganos, que la sola circunstancia de que la materia que da causa a la controversia contencioso-administrativa se vincule subjetivamente con alguno de los órganos o autoridades públicas que la constitución y la ley establecen, no es en modo alguno suficiente para descartar su disponibilidad en derecho y, desde allí, para rechazar por ende su arbitrabilidad en cuanto tal. Antes por el contrario, el análisis de arbitrabilidad deberá escudriñar más

45 Comentando esta misma sentencia, Rossani señala que en ella el tribunal referido "sustentó que la cláusula [arbitral] es válida, siendo dispensable la necesidad de autorización del Poder Legislativo estatal para que se pueda efectuar tal procedimiento". (Rossani Garcez (2007) p. 96. Traducción libre del autor.)

46 Traducción libre del autor. 
allá todavía y centrarse en la concreta pretensión procesal que se dirige al árbitro, pues solo así podrá definirse si la controversia que le sirve de marco puede o no ser resuelta por esta vía alternativa. Solo conociendo el contenido de la pretensión podrá descubrirse, en fin, si la controversia que sirve de objeto al arbitraje afecta en definitiva al ejercicio de potestades privativas y/o al ámbito reglado de actuación del respectivo órgano público, o si, en cambio, de lo que se trata es de solucionar simplemente conflictos que apuntan a las consecuencias patrimoniales de los actos en que interviene la administración, ya sea como parte de su actividad negocial con los particulares o, en último término, como resultado de la responsabilidad que le asiste en el orden extracontractual ${ }^{47}$.

No resulta necesario que la ley autorice expresamente al ente público para recurrir a arbitraje en los casos propuestos, pues para ello basta con que la norma legal lo faculte en términos amplios para disponer discrecionalmente de las consecuencias negociales del ejercicio de su propia potestad. Es lo que ocurre, por ejemplo, con aquellas normas legales que facultan al respectivo órgano administrativo para transigir ${ }^{48}$, judicial o extrajudicialmente, en donde la opción por el arbitraje no es más que un poder inherente a la primera, inherent power en la denominación anglosajona ${ }^{49}$.

\section{BIBLIOGRAFÍA CITADA}

Aravena Arredondo, Leonardo (1969): Naturaleza del arbitraje (Edit. Jurídica de Chile, Santiago).

Ballesteros Ríos, Manuel Egidio (1890): La Lei de Organización i Atribuciones de los Tribunales de Chile, Tomo II (Imprenta Nacional, Santiago).

Carmona santander, Carlos (2005): "El contencioso administrativo entre 1990 y 2003", en La Justicia Administrativa, AA.VV (coord. Juan Carlos Ferrada Bórquez) (Universidad Austral de Chile, Editorial LexisNexis).

Carazo Liébana, María José (2005): El arbitraje societario (Marcial Pons, Madrid).

Cazor Aliste, Kamel y Pfeffer Urquiaga, Emilio (2009): "La búsqueda de criterios orientadores en la configuración de las potestades normativas en Chile"., en "Ius et Praxis", Año $15, \mathrm{~N}^{\circ} 1$.

De La Cuétara, Juan Miguel (1986): Las Potestades Administrativas (Tecnos S.A., Madrid). Delgado Piqueras, Francisco (1985): "Algunas aportaciones de la Ley de Régimen Jurídico de las Administraciones Públicas y del Procedimiento Administrativo Común al de-

\footnotetext{
47 Cfr. Merino y Chillón (2006) pp. 287 y ss.

48 En la ley española y concretamente en relación con el art. 77 de la Ley reguladora de la Jurisdicción Contencioso-Administrativo, de 13 de julio de 1998, puede consultarse a GARCÍA DE Enterría y Fernández (2000) pp. 663 y 664 .

49 Como dice De la CuÉtara, refiriéndose al sistema anglosajón, la doctrina de los poderes inherentes se encuentra destinada precisamente a evitar que se considere una acción administrativa como excesiva o "más allá de las propias fuerzas", esto es, "para establecer que cualquier acción que honestamente -fairly- pueda ser entendida como incidental o consecuente con un poder autorizado por la legislatura no debe considerarse ultra vires". [De la Cuétara (1986) p. 83].
} 
bate actual sobre la conceptualización del Derecho administrativo, en Revista española de Derecho Administrativo, N85/1995, parte Estudios, Civitas, Madrid.

D'Angeli, Fiorella (1996): L'arbitrato convenzionale ed imposto facultativo ed inverso (G. Giappichelli Editore, Torino).

Fernández González, Miguel Ángel (2002): “Fundamentos Constitucionales del Derecho de los Contratos: Intangibilidad, Autonomía de la Voluntad y Buena Fe", en Cuadernos de Extensión Jurídica, No 6, Universidad de los Andes, Santiago de Chile.

García de Enterría, Eduardo (1989): Hacia una nueva justicia administrativa, (Civitas, Madrid).

García de Enterría, Eduardo (1983): La lucha contra las inmunidades del poder (Civitas, $3^{\text {a }}$ ed., Madrid).

García de Enterría, Eduardo (1997): Democracia, Jueces, Control de la Administración (Civitas, Madrid).

García de Enterría, Eduardo y Fernández, Tomás Ramón (2000): Curso de Derecho Administrativo, Tomo II, 10a ed. (Aranzadi S.A., Navarra).

García de Enterría, Eduardo y Fernández, Tomás Ramón (2006): Curso de Derecho Administrativo, Tomo I, 13a (ed., Aranzadi S.A., Navarra).

Gutiérrez Araque, María José (2008): "La mediación en salud y el acceso a la justicia”, en Revista de Derecho, Consejo de Defensa del Estado, Vol. 20, diciembre de 2008.

La China, Sergio (2004): L'Arbitrato. Il sistema e l'sperienza, 2a ed. (Giuffré, Milán).

Merino Merchán, José F. y Chillón Medina, José Ma (2006): Tratado de Derecho Arbitral (Civitas, Navarra).

Montero Aroca, Juan (2004): "Materias objeto de arbitraje", en Comentarios a la Ley de Arbitraje (Ley 60/2003 de 23 de diciembre), VV.AA. (coord. Silvia Barona Vilar), Civitas, Madrid.

Montero Aroca, Juan (2000): Derecho jurisdiccional, Tomo I, Parte General, 10a ed. (Tirant, Valencia).

Moraga Klenner, Claudio (2007): Contratación Administrativa (Editorial Jurídica de Chile, Santiago).

Moraga Klenner, Claudio (2008): "Derecho público chileno, y los principios de legalidad administrativa y de juridicidad”, en Derecho Administrativo. 120 años de cátedra, VV.AA., (coord. Rolando Pantoja Bauzá) (Editorial Jurídica de Chile).

Pereira Anabalón, Hugo (1996): “Competencia de árbitro arbitrador para conocer de una demanda declarativa de nulidad de una cláusula compromisoria”, en Gaceta Jurídica, No 187, ConoSur, Santiago de Chile.

Puelma Accorsi, Alvaro (2001): Sociedades, 3a ed., Dos Tomos (Editorial Jurídica de Chile, Santiago de Chile).

Rodríguez Muñoz, José Luis: (2011) “El sometimiento de los derechos de la hacienda pública a arbitraje o transacción”, en "Quincena Fiscal Aranzadi”, N 17, parte Estudio (Edit. Aranzadi, Pamplona).

Romero Seguel, Alejandro (1999): "Panorama general de la justicia arbitral en Chile”, en Revista Vasca de Derecho Procesal y Arbitraje, Tomo XI, Universidad del País Vasco, Septiembre 1999. 
Eduardo "La arbitrabilidad de la controversia contencioso-administrativa..."

Rossani Garcez, José María (2007): Arbitragem Nacional e Internacional. Progressos Recentes (Del Rey, Belo Horizonte).

SaAvedra Fernández, Rubén (2011): Discrecionalidad Administrativa, (AbeledoPerrot LegalPublishing Chile, Santiago).

Santamaría Pastor, Juan Alfonso (1988): Fundamentos de Derecho Administrativo I (Editorial Centro de Estudios Ramón Areces, Madrid).

Santi Romano (2002): Fragmentos de un Diccionario Jurídico (Comares, Granada).

VÁsquez Palma, Ma. Fernanda (2009): Arbitraje en Chile. Análisis crítico de su normativa y jurisprudencia (Legal-Publishing, Santiago de Chile).

Vedel, Georges (1980): Derecho Administrativo, traducción especial de la 6a ed. (Francesa, Aguilar, Madrid).

Vicent Chuliá, Francisco (2001): "Arbitraje de Impugnación de Acuerdos Sociales. Acto Final”, en Anuario Justicia Alternativa, Año 2001, Nº 1, Barcelona. 